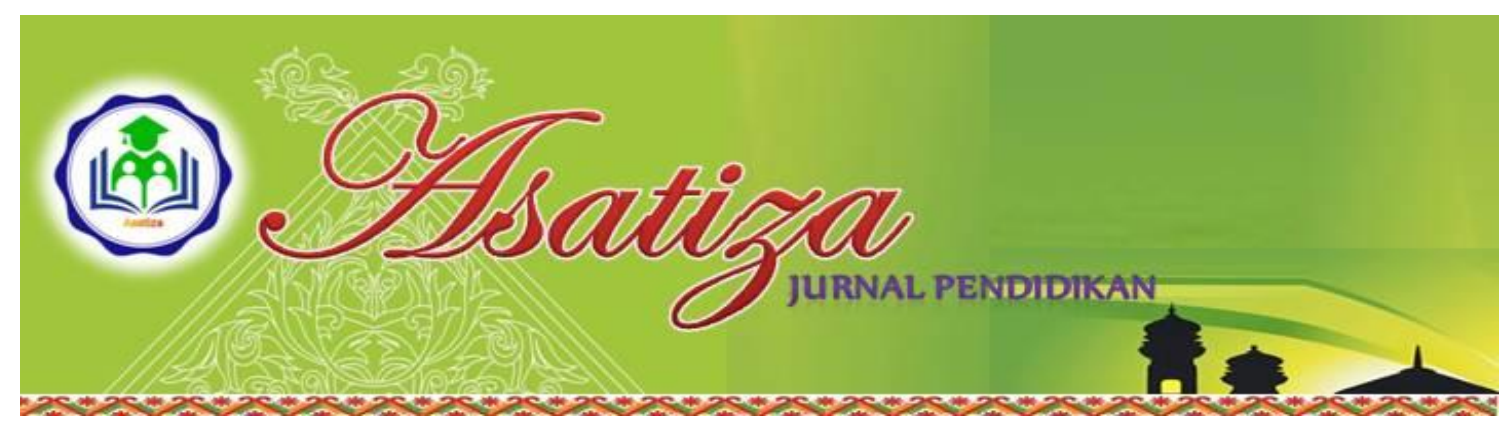

\title{
PENGARUH SERTIFIKASI TERHADAP KEDISIPLINAN MENGAJAR GURU DI SEKOLAH DASAR NEGERI 008 TEMBILAHAN HULU
}

\author{
Misna Juwita $^{1}$; Deddy Yusuf Yudhyarta ${ }^{2}$ \\ ${ }^{1}$ STAI Auliaurrasyidin Tembilahan; ${ }^{2}$ STAI Auliaurrasyidin Tembilahan
}

\begin{abstract}
Abstrak
Penelitian ini bertujuan Untuk mengetahui bagaimana Pengaruh Sertifikasi Terhadap Kedisiplinan Mengajar Guru dan apakah ada Pengaruh Sertifikasi Terhadap Kedisiplinan Mengajar Guru di Sekolah Dasar Negeri 008 Tembilahan Hulu.

Subjek dari penelitian ini adalah guru PAI di Sekolah Dasar Negeri 008 Tembilahan Hulu. Objek dalam penelitian ini adalah Pengaruh Sertifikasi Terhadap Kedisiplinan Mengajar Guru di Sekolah Dasar Negeri 008 Tembilahan Hulu.Populasi dalam penelitian ini adalah guru PAI yang berjumlah 2 orang. Teknik pengumpulan data melalui observasi dan dokumentasi. Teknik analisa datanya dilakukan dengan teknik statistik uji korelasi pearson product moment.

Dari hasil data diperoleh hasil bahwa berdasarkan perhitungan pada taraf signifikansi $5 \%$ diperoleh ttabel $=1,943$. Ternyata thitung lebih besar dari ttabel atau thitung: $12 \geq$ tabel: 1,943 , maka Ha diterima dan Ho ditolak, artinya ada Pengaruh yang signifikan antara Sertifikasi Terhadap Kedisiplinan Mengajar Guru di Sekolah Dasar Negeri 008 Tembilahan Hulu
\end{abstract}

Kata Kunci: Sertifikasi, Kedisiplinan Mengajar

\section{A. PENDAHULUAN}

\section{Latar belakang}

Era globalisasi yang ditandai dengan persaingan kualitas atau mutu menuntut semua pihak dalam berbagai bidang dan sektor pembangunan untuk senantiasa meningkatkan kompetensinya. Hal tersebut mendudukan pentingnya upaya peningkatan kualitas pendidikan baik secara kuantitatif maupun kualitatif yang harus dilakukan terus menerus sehingga pendidikan dapat digunakan sebagai wahana dalam membangun watak bangsa(nation character) untuk itu guru sebagai main person harus di tingkatkan kompetensinya dan diadakan sertifikasi sesuai dengan pekerjaan yang diembannya.Dalam kerangka inilah pemerintah merasa perlu mengembangkan Standar Pendidikan Nasional (SPN) \& Standar Nasional Indonesia (SNI). ${ }^{1}$

${ }^{1}$ Mulyasa, E. Standar kompetensi dan Sertifikasi Guru, (bandung: PT Remaja Rosdakarya, 2009), hlm. 17. 
Berdasarkan kenyataan yang ada pemerintah telah mengupayakan berbagai hal diantaranya sertifikasi guru dengan adanya program sertifikasi tersebut diharapkan kualitas mengajar guru akan lebih baik.

Dalam undang-undang no.14 tahun 2005 tentang guru dan dosen dikemukakan bahwa sertifikasi adalah proses pemberian sertifikat pendidik untuk guru dan dosen. Sedangkan sertifikat pendidik adalah bukti formal sebagai pengakuan yang diberikan kepada guru dan dosen sebagai tenaga profesional. $^{2}$

Secara subtansialnya lebih disebabkan munculnya tuntutan kerja yang berbasis pada kinerja, berbasis pada hasil dan kepuasan pelayanan. Tuntutan demikian segera menggeser kecenderungan selama ini bahwa penghargaan (upah) kerja seseorang di ukur berdasarkan waktu atau jumlah hari dan bukan sejauh mana volume, kualitas dan mutu pekerjaan yang bisa dihasilkan dari seorang pekerja dengan demikian profesionalisme menjadi standar seberapa besar kualitas ataupun kinerja seseorang. ${ }^{3}$

Sertifikasi Guru merupakan amanat undang-undang RI No.20 tahun 2003 tentang Sisdiknas.Pasal 61 menyatakan bahwa sertifikasi dapat berbentuk ijazah dan sertifikasi kompetensi tetapi bukan sertifikat yang di peroleh melalui pertemuan ilmiah seperti seminar, diskusi panel, lokakarya dan simposium.

Namun sertifikat kompetensi diperoleh dari penyelenggara pendidikan dan lembaga pelatihan setelah lulus uji kompetensi yang diselanggarakan oleh

${ }^{2}$ Ibid., hlm. 33.

${ }^{3}$ Ibid., hlm. 2. satuan pendidikan yang terakreditasi atau lembaga sertifikasi ketentuan ini bersifat umum baik untuk tenaga kependidikan maupun non kependidikan yang ingin memasuki profesi guru. ${ }^{4}$

Dengan adanya sertifikasi ini guru merasa terbantu karena bagi guru yang telah memiliki sertifikasi dan persyaratan lain akan mendapatkan tunjangan profesi yang besarnya sama dengan gaji satu bulan dengan demikian diharapkan seorang guru dapat mengajar secara lancar tanpa terkendala masalah ekonomi.

Namun yang terjadi saat ini sering dijumpai bahwasanya niatan guru mengejar sertifikasi bukan untuk mengembangkan pengetahuan tentang pendidikan akan tetapi hanyalah faktor uanglah yang mendorong kebanyakan guru untuk melakukan sertifikasi. Apalagi setelah mereka mengetahui bahwasanya tunjangan yang mereka dapatkan apabila sudah sertifikasi cukup besar apalagi yang harus dipertahankan dari kebijakan sertifikasi guru ini jika hanya mendidik guru untuk berperilaku matre.

Guru yang memiliki kompetensi dituntut harus bersikap profesional dalam mengemban tugasnya sebagai pendidik yakni mendidik, mengajar, membimbing, mengarahkan, melatih, menilai, dan mengevaluasi peserta didik pada pendidikan anak usia dini jalur pendidikan formal, pendidikan dasar, dan pendidikan menengah. ${ }^{5}$

Tetapi realitanya dilapangan masih banyak guru-guru yang kurang disiplin

\footnotetext{
${ }^{4}$ Mulyasa, E, Op. Cit., hlm. 39.

${ }^{5}$ Kusnadi, Op.Cit., hlm. 11.
} 
dalam mengajar yang terjadi disekolahsekolah baik di SD maupun SMA.

Seperti diSekolah Dasar Negeri 008 Tembilahan Hulu masih adanya guru yang tidak disiplin dalam mengajar, masih adanya guru yang terlambat datang ke sekolah sehingga waktu mengajarnya tidak terpenuhi, kurangnya tanggung jawab guru terhadap bahan ajar sehingga dalam pembelajaran tujuannya tidak tercapai, ada guru yang bersertifikasi tetapi tidak sesuai dengan standar kompetensinya.

\section{Pengertian Sertifikasi Guru}

Peraturan pemerintah RI no.74 tahun 2008 tentang guru (2008:4) pasal 1 menjelaskan bahwa:

a. Sertifikasi adalah proses pemberian sertifikasi pendidik untuk guru.

b. Sertifikat pendidik adalah bukti formal sebagai pengakuan yang diberikan kepada guru sebagai tenaga profesional.

Menurut Parida Srimaya, program sertifikasi guru adalah program yang berisi tentang proses pemberian sertifikat pendidik guru. Guru yang telah mengikuti program sertifikasi dan dinyatakan lulus akan memperoleh sertifikasi profesi guru sebagai tenaga profesional. Secara garis besar program sertifikasi guru dibedakan menjadi dua:

a. Program sertifikasi untuk guru yang telah ada (guru dalam jabatan).

${ }^{6}$ Martinis Yamin, Maisah, Standarisasi Kinerja Guru, (Jakarta: Gaung Persada, 2010), hlm. 150.

${ }^{7}$ Mulyasa, E, Standar Kompetensi dan Sertifikasi Guru, (Bandung: PT Remaja Rosdakarya, 2009), hlm. 34. b. Program sertifikasi untuk calon guru. ${ }^{6}$

Dalam hal ini sertifikasi merupakan prosedur untuk menentukan apakah seorang calon guru layak diberikan izin dan kewenangan untuk mengajar. Hal ini diperlukan karena lulusan lembaga pendidikan tenaga keguruan sangat bervariasi, baik dikalangan perguruan tinggi negeri maupun swasta. ${ }^{7}$

Di Indonesia menurut UU RI No.14 tahun 2005 tentang guru dan dosen, sertifikat pendidikan diberikan kepada guru yang telah memenuhi persyaratan kualifikasi akademik dan kompetensi sebagai agen pembelajaran. Sertifikat pendidik diberikan kepada seseorang yang telah menyelesaikan program pendidikan profesi pendidik dan lulus uji sertifikasi pendidik. Dalam hal ini uji sertifikasi pendidik dimaksudkan sebagai kontrol mutu hasil pendidikan sehingga seseorang yang dinyatakan lulus dalam uji sertifikasi pendidik diyakini mampu melaksanakan tugas, mendidik, mengajar, melatih, membimbing, dan menilai hasil belajar peserta didik. $^{8}$

Secara konseptual, seorang guru harus memiliki sertifikat pendidik yang untuk memperolehnya harus melalui uji sertifikasi pendidik. Sebelum mengikuti uji sertifikasi, seharusnya yang bersangkutan mengikuti program pendidikan profesi yaitu pendidikan tinggi setelah S1 atau Diploma IV yang mempersiapkan peserta didik untuk

${ }^{8}$ J. B. Situmorang, Winarno, Pendidikan Profesi dan Sertifikasi Pendidik, (Klaten: Saka Mitra Kompetensi, 2008), hlm. 38. 
memiliki pekerjaan dengan persyaratan keahlian khusus sesuai dengan standar kompetensi. ${ }^{9}$

Peningkatan kualifikasi guru disamping untuk meningkatkan kompetensinya, sehingga layak untuk menjadi guru yang profesional juga dimaksudkan agar guru yang bersangkutan dapat mengikuti uji sertifikasi setelah memperoleh ijazah S1/D4 serta mengikuti pendidikan profesi. Pemberian bantuan biaya pendidikan untuk meningkatkan guru wajib memiliki kualifikasi akademik, kompetensi, sertifikasi pendidik, sehat jasmani dan rohani, serta memiliki kemampuan untuk mewujudkan tujuan pendidikan nasional.

Program sertifikasi dilaksanakan untuk meningkatkan mutu dan martabat guru. Hal ini dilakukan mengingat guru mempunyai kedudukan yang strategis sebagai tenaga profesional pada jenjang pendidikan dasar, pendidikan menengah dan pendidikan anak usia dini pada jalur pendidikan formal yang diangkat sesuai dengan peraturan perundang-undangan kedudukan guru sebagai tenaga profesional berfungsi untuk meningkatkan martabat dan peran guru sebagai agen pembelajaran berfungsi untuk meningkatkan mutu pendidikan nasional. Kedudukan guru tenaga profesional bertujuan untuk melaksanakan sistem pendidikan nasional dan mewujudkan tujuan menjadi manusia yang:

a. Beriman dan bertaqwa kepada tuhan yang maha esa.

b. Berakhlak mulia.

${ }^{9}$ Ibid., hlm. 31. c. Sehat.

d. Berilmu.

e. Cakap.

f. Kreatif.

g. Mandiri

h. Menjadi warga negara yang demokratis dan bertanggung jawab. ${ }^{10}$

Profesi guru merupakan bidang pekerjaan khusus yang dilaksanakan berdasarkan prinsip, sebagai berikut:

a. Memiliki bakat, minat, panggilan jiwa dan idealism.

b. Memiliki komitmen untuk meningkatkan mutu pendidikan, keimanan, ketaqwaan dan akhlak mulia.

c. Memiliki kualifikasi akademik dan latar belakang pendidikan yang sesuai dengan bidang tugas.

d. Memiliki kompetensi yang diperlukan sesuai dengan bidang tugas.

e. Memiliki tanggung jawab atas pelaksanaan tugas profesional.

f. Memperoleh penghasilan yang ditentukan sesuai dengan prestasi kerja.

g. Memiliki kesempatan untuk mengembangkan keprofesionalan secara berkelanjutan dengan belajar sepanjang hayat.

h. Memiliki jaminan perlindungan hukum dalam melaksanakan tugas profesional, dan

i. Memiliki organisasi profesi yang mempunyai kewenangan mengatur hal-hal yang berkaitan dengan tugas profesional guru.

\footnotetext{
158.

${ }^{10}$ Martinis Yamin, Maisah, Op.Cit., hlm.
} 
Pemberdayaan profesi guru diselenggarakan melalui pangembangan diri yang dilakukan secara demokratis, berkeadilan, tidak diskriminatif dan berkelanjutan dengan menjunjung tinggi hak asasi manusia, nilai keagamaan, nilai kultural, kemajemukan bangsa dan kode profesi. $^{11}$

Pelaksanaan sertifikasi dapat dipilah menjadi dua, yaitu: (1) tes dan (2) non tes. Komponen tes meliputi, (1) tes tulis dan (2) tes kinerja sedangkan komponen non tes meliputi (1) self appraisal.(2) portofolio dan (3) (3) penilaian atasan.Tes tulis dilaksanakan serentak diseluruh indonesia, sedangkan tes kinerja dilaksanakan sesudah tes tulis dan diselenggarakan disekolah tempat peserta mengajar atau sekolah lain yang di tunjukan (real teaching). Waktu pelaksanaan tes kinerja diatur oleh dinas pendidikan kab/kota dan LPTK penyelenggaraan. ${ }^{12}$

\section{Tujuan dan Manfaat sertifikasi guru}

Tujuan sertifikasi adalah untuk meningkatkan kualitas guru yang pada akhirnya diharapkan berdampak pada peningkatan mutu pendidikan guru dalam jabatan yang telah memenuhi syarat dapat mengikuti proses sertifikasi untuk mendapat sertifikat pendidik.

Dalam APBN-P tahun 2006, Depdiknas menargetkan untuk dapat melakukan uji sertifikasi terhadap 20.000 guru. Prioritas uji sertifikasi tahap awal ini adalah guru-guru yang mengajar dijenjang pendidikan dasar
(SD dan SMP) yang telah memenuhi persyaratan. Adapun manfaat uji sertifikasi pendidik adalah:

a. Melindungi profesi pendidik dari praktik-praktik yang tidak kompeten sehingga merusak citra profesi pendidik.

b. Melindungi masyarakat dari praktik-praktik pendidikan yang tidak berkualitas.

c. Menjadi wahana penjaminan mutu bagi lembaga pendidikan tenaga pendidik (LPTK, dan kontrol mutu bagi pengguna layanan pendidikan serta

d. Menjaga lembaga penyelenggara pendidikan dari keinginan internal dan tekanan eksternal yang menyimpang dari ketentuanketentuan yang berlaku. ${ }^{13}$

\section{Peranan dan kompetensi Guru dalam proses Mengajar Belajar}

Guru merupakan jabatan atau profesi yang memerlukan keahlian khusus sebagai guru. pekerjaan ini tidak bisa dilakukan oleh orang yang tidak memiliki keahlian untuk melakukan kegiatan atau pekerjaan sebagai guru.Orang yang pandai berbicara dalam bidang-bidang tertentu belum dapat disebut sebagai guru untuk menjadi guru diperlukan syarat-syarat khusus, apalagi sebagai guru yang profesional yang harus menguasai betul seluk beluk pendidikan dan pengajaran dengan berbagai ilmu pengetahuan lainnya yang perlu dibina dan dikembangkan melalui masa

\footnotetext{
${ }^{13}$ J.B. Situmorang, Winarno, op.cit., hlm. 34.
}

Ibid., hlm. 159. 
pendidikan tertentu atau pendidikan tertentu atau pendidikan prajabatan. ${ }^{14}$

Tugas guru sebagai profesi meliputi mendidik, mengajar, dan melatih. Mendidik berarti meneruskan dan mengembangkan nilai-nilai hidup. Mengajar berarti meneruskan dan mengembangkan ilmu pengetahuan dan teknologi sedangkan melatih berarti mengembangkan ketrampilanketrampilan pada siswa.

Mengajar merupakan suatu perbuatan yang memerlukan tanggung jawab morel yang cukup berat. Berhasilnya pendidikan pada siswa sangat bergantung pada pertanggung jawaban guru dalam melaksanakan tugasnya. Mengajar pada prinsipnya membimbing siswa dalam kegiatan belajar mengajar atau mengandung pengertian bahwa mengajar merupakan suatu usaha mengorganisasi lingkungan dalam hubungannya dengan anak didik dan bahan pengajaran yang menimbulkan proses belajar. ${ }^{15}$

Pengertian ini mengandung makna bahwa guru dituntut untuk dapat berperan sebagai organisator kegiatan belajar siswa dan juga hendaknya mampu mamanfaatkan lingkungan, baik yang ada dikelas maupun yang ada diluar kelas, yang menunjang kegiatan belajar mengajar. Dalam pengertian lain dikatakan bahwa teaching is the guidance of learning activies.

Keberhasilan guru melaksanakan peranannya dalam bidang pendidik sebagian besar terletak pada kemampuannya melaksanakan berbagai

${ }^{14}$ Moh. Uzer Usman, Menjadi Guru Profesional, (Bandung: PT Remaja Rosdakarya, 2004), hlm. 5. peranan yang bersifat khusus dalam situasi mengajar dan belajar.

Berdasarkan studi literatur terhadap pandangan Adams dan Dickey dalam bukunya Basic Principles of Student Teaching, dapat ditarik kesimpulan bahwa paling tidak terdapat 13 peranan guru di dalam kelas (dalam situasi belajar mengajar). Tiap peranan menuntut berbagai kompetensi atau keterampilan mengajar, yaitu:

a. Guru sebagai pengajar, menyampaikan ilmu pengetahuan perlu memiliki keterampilan memberikan informasi kepada kelas.

b. Guru sebagai pemimpin kelas, perlu memiliki keterampilan cara memimpin kelompok-kelompok murid.

c. Guru sebagai pembimbing, perlu memiliki keterampilan cara mengarahkan dan mendorong kegiatan belajar siswa.

d. Guru sebagai pengatur lingkungan, perlu memiliki keterampilan mempersiapkan dan menyediakan alat dan bahan pelajaran.

e. Guru sebagai partisipan, perlu memiliki keterampilan cara memberikan saran, mengarahkan pemikiran kelas dan memberikan penjelasan.

f. Guru sebagai ekspeditu, perlu memiliki keterampilan menyelidiki sumber-sumber masyarakat yang akan digunakan.

\footnotetext{
${ }^{15}$ Ibid., hlm. 6-7.
} 
g. Guru sebagai perencana, perlu memiliki keterampilan cara memilih dan meramu dahan pelajaran secara profesional.

h. Guru sebagai supervisor, perlu memiliki ketermpilan mengawasi kegiatan anak dan ketertiban kelas.

i. Guru sebagai motivator, perlu memiliki ketrampilan mendorong motivasi belajar kelas.

j. Guru sebagai penanya, perlu memiliki keterampilan cara bertanya yang merangsang kelas berpikir dan cara memecahkan masalah.

k. Guru sebagai pengganjar, perlu memiliki keterampilan cara memberikan penghargaaan terhadap anak-anak yang berprestasi.

1. Guru sebagai evaluator, perlu memiliki keterampilan cara menilai anak-anak secara objektif, kontinu, dan komprehensif.

m. Guru sebagai konselor, perlu memiliki keterampilan cara membantu anak-anak yang mengalami kesulitan tertentu. ${ }^{16}$

\section{Pengertian kedisiplinan guru dalam proses belajar mengajar}

Konsep disiplin berkaitan dengan tata tertib, aturan, atau norma dalam kehidupan bersama (yang melibatkan orang banyak). Menurut Moeliono disiplin artinya adalah ketaatan

${ }^{16}$ Oemar Hamalik, Pendidikan Guru Berdasarkan Pendekatan Kompetensi, (Jakarta: PT Bumi Aksara, 2004), hlm. 48-49.

${ }^{17}$ Sardiman, Am, Interaksi dan Motivasi Belajar Mengajar, (Jakarta: PT Raja Grafindo Persada, 2001), hlm. 123. (kepatuhan)kepada peraturan tata tertib, aturan atau norma dan lain sebagainya. Sedangkan pengertian guru adalah suatu komponen manusia dalam proses belajar mengajar yang ikut berperan aktif dalam usaha pembentukan sumber daya manusia. ${ }^{17}$

Sedangkan Dimyati, dalam bukunya mengatakan bahwa guru adalah semua orang berwenang dan bertanggung jawab terhadap pendidikan murid baik secara individual maupun klasikal, baik disekolah maupun diluar sekolah. ${ }^{18}$

Ini berarti bahwa seorang guru minimal harus memiliki dasar-dasar kompetensi sehingga memiliki wewenang dan kemampuan dalam menjalankan tugasnya terutama agar dapat meningkatkan suasana belajar yang kondusif.

Dalam rangka peningkatan disiplin guru ada tiga hal yang perlu diperhatikan oleh seorang guru, yaitu: Kehadiran, Pelaksanaan tugas (kegiatan). Program tindak lanjut. ${ }^{19}$

Dari uraian diatas, jelaslah bahwa kedisiplinan guru merupakan suatu ketaatan (kepatuhan) guru terhadap tata tertib(aturan) yang berkaitan dengan pelaksanaan tugasnya sebagai tenaga pendidik dalam proses belajar mengajar disekolah.Berkenaan dengan hal itu, maka teori dasar yang dikembangkan sebagai dimensi dan indikator kedisiplinan guru dalam proses belajar mengajar adalah mencakup tiga aspek,

${ }^{18}$ Dimyati, Mudjiono, Belajar dan Pembelajaran, (Jakarta: PT Rineka Cipta, 2000), hlm. 25.

${ }^{19}$ Dirjen Dikdasmen, Pengelolaan Sekolah di Sekolah Dasar, (Jakarta: Depdikbud, 1996), hlm. 10. 
yaitu kehadiran, pelaksanaan tugas(kegiatan), dan program tindak lanjut dengan alasan untuk mengetahui sejauhmana tingkat kedisiplinan guru. Dalam menjalankan tugasnya sebagai pendidik disekolah.

Dalam pendidikan, mendisiplinkan peserta didik harus dimulai dengan pribadi guru yang disiplin, arif, dan berwibawa.Kita tidak bisa berharap banyak akan terbentuknya peserta didik yang disiplin dari pribadi guru yang kurang disiplin, kurang arif dan kurang berwibawa.Oleh karena itu, sekaranglah saatnya kita membina disiplin peserta didik dengan pribadi guru yang disiplin, arif, dan berwibawa.Dalam hal ini disiplin harus ditujukan untuk membantu peserta didik menemukan diri, mengatasi, mencegah timbulnya masalah disiplinan dan berusaha menciptakan situasi yang menyenangkan bagi kegiatan pembelajaran, sehingga mereka mentaati segala peraturan yang telah ditetapkan.

\section{B. METODOLOGI}

Subjek dari penelitian ini adalah guru PAI di Sekolah Dasar Negeri 008 Tembilahan Hulu. Objek dalam penelitian ini adalah Pengaruh Sertifikasi Terhadap Kedisiplinan Mengajar Guru di Sekolah Dasar Negeri 008 Tembilahan Hulu Yang menjadi populasi dalam penelitian ini adalah guru di Sekolah Dasar Negeri 008 Tembilahan Hulu yang berjumlah 18 orang guru yang memiliki sertifikasi dari 33 orang. Teknik

${ }^{20}$ Riduwan, Belajar Mudah Peneitian Untuk Guru Karyawan dan Peneliti Pemula, (Bandung: Alfabeta,2004), hlm. 222.
Pengumpulan Data adalah observasi dan dokumentasi.

Data yang sudah terkumpul penulis kualifikasikan atau tuangkan ke dalam bentuk angka-angka sehingga data tersebut bersifat kuantitatif untuk selanjutnya di analisa dan diinterprestasikan secara deskriptif.

Pengalihan data kedalam bentuk kuantitatif ini ditempuh dengan menggunakan rumus Product moment person:

$r x y=\frac{N\left(\sum X \cdot y\right)-\left(\sum x\right) \cdot\left(\sum y\right)}{\sqrt{\left(\left[N \cdot \sum \mathrm{X}^{2}-\left(\sum \llbracket \mathrm{X}\right) \rrbracket^{2}\right]-\left[\mathrm{N} \cdot \sum \mathrm{Y}^{2}\right)-\left(\sum \mathrm{y}\right)^{2}\right]}}$

Keterangan:

$\begin{array}{ll}\mathrm{r}_{\text {hitung }} & =\text { Koefisien korelasi } \\ \sum \mathrm{X} & =\text { Jumlah skor items } \mathrm{X} \\ \sum \mathrm{y} & =\text { Jumlah skor total } \\ \mathrm{N} & =\text { Jumlah responden }\end{array}$

Korelasi Pearson Product Moment dilambangkan dengan (r) dengan ketentuan nilai $r$ tidak lebih dari harga ($1 \leq \mathrm{r} \leq+1)$ apabila nilai $\mathrm{r}=-1$ artinya korelasinya negative sempurna, $r=0$ artinya tidak ada korelasi; dan $\mathrm{r}=1$ berarti korelasinya sangat kuat. ${ }^{20}$

Sedangkan harga $r$ akan dikonsultasikan dengan tabel interprestasi nilai r, sebagai berikut:

Interprestasi Koefesien Korelasi

Nilai $r$

\begin{tabular}{|c|c|}
\hline $\begin{array}{c}\text { Interval } \\
\text { Koefesien }\end{array}$ & Tingkat Hubungan \\
\hline $0,80-1,000$ & Sangat Baik \\
$0,60-0,799$ & Baik \\
$0,40-0,599$ & Cukup Baik \\
$0,20-0,399$ & Kurang Baik \\
$0,00-0,199$ & Tidak Baik \\
\hline
\end{tabular}

Selanjutnya untuk menyatakan besar kecilnya sumbangan variabel $\mathrm{X}$ terhadap 
Y dapat ditentukan dengan rumus koefesien di terminan sebagai berikut:

$$
\mathrm{KP}=\mathrm{r}^{2} \mathrm{X} 100 \%
$$

Dimana:

$$
\begin{aligned}
\mathrm{KP} & =\text { Nilai Koefesien Di terminan } \\
\mathrm{r} & =\text { Nilai Koefesien Korelasi }
\end{aligned}
$$

Pengujian lanjutan yaitu uji signifikan yang berfungsi apabila peneliti ingin mencari makna hubungan variable $\mathrm{X}$ terhadap Y, maka Person Product Moment tersebut di uji signifikan dengan rumus:

$$
t_{\text {hitung }}=\frac{\sqrt[r]{n-2}}{\sqrt{I-r^{2}}}
$$

Keterangan:

$$
\mathrm{T}=\text { Nilai } t_{\text {hitung }}
$$

$\mathrm{R}=$ Koefesien Korelasi hasil $\mathrm{r}_{\text {hitung }}$

$\mathrm{n}=$ Jumlah responden $^{21}$

Untuk memudahkan dalam penganalisaan hasil penelitian, penulis menggunakan teknik korelasi Product Moment. Maka menurut Riduwan ${ }^{22}$, terdapat langkah-langkah dalam penganalisaan, yaitu sebagai berikut:

1. Membuat Ha dan Ho dalam bentuk kalimat.

2. Membuat tabel penolong untuk menghitung angka statistik.

3. Kemudian mencari $\mathrm{r}_{\text {hitung }}$ dengan dari table penolong dengan menggunakan rumus:

$r x y=\frac{N\left(\sum X \cdot y\right)-\left(\sum x\right) \cdot\left(\sum y\right)}{\left.\sqrt{\left[N \cdot \sum \mathrm{X}^{2}-\left(\sum \mathrm{X}\right)^{2}\right]-\left[N \cdot \sum \mathrm{Y}^{2}\right.}-\left(\sum \mathrm{y}\right)^{2}\right]}$

4. Kemudian untuk mencari besarnya sumbangan (Kontribusi) variabel $\mathrm{X}$ terhadap $\mathrm{Y}$ dengan rumus:

$\mathrm{KP}=\mathrm{r}^{2} \mathrm{X} 100 \%$. cara memasukkan angka statistik

5. Kemudian dilakukan pengujian signifikansi dengan rumus $t_{\text {hitung: }}$ $t_{\text {hitung }}=\frac{\sqrt[r]{n-2}}{\sqrt{n-r^{2}}}$

6. Membuat kesimpulan

Dan untuk memperoleh skor dari pertanyaan hasil angket penulis menggunakan skala interval yaitu "Skala yang menunjukkan jarak antara satu data dengan data yang lain ${ }^{23}$," yaitu sebagai berikut:

$\begin{array}{lc}\text { Selalu } & =5 \\ \text { Sering } & =4 \\ \text { Jarang } & =3 \\ \text { Kadang-Kadang } & =2 \\ \text { Tidak Pernah } & =1^{24}\end{array}$

\section{PEMBAHASAN}

Untuk mengetahui ada pengaruh antara dua variabel atau lebih maka digunakan data penolong untuk menghitung angka statistik sebagai berikut:

Tabel Korelasi Product Moment Variabel $X$ dan Variabel $Y$

Tabel Penolong

\begin{tabular}{|c|c|c|c|c|c|}
\hline No & $\mathbf{X}$ & $\mathbf{Y}$ & $\mathbf{X . Y}$ & $\mathbf{X}^{\mathbf{2}}$ & $\mathbf{Y}^{\mathbf{2}}$ \\
\hline 1 & 34 & 39 & 1326 & 1156 & 1521 \\
2 & 40 & 51 & 2040 & 1600 & 2601 \\
3 & 35 & 41 & 1435 & 1225 & 1681 \\
4 & 40 & 53 & 2120 & 1600 & 2809 \\
5 & 32 & 40 & 1280 & 1024 & 1600 \\
6 & 39 & 52 & 2028 & 1521 & 2704 \\
7 & 36 & 42 & 1512 & 1296 & 1764 \\
8 & 42 & 51 & 2142 & 1764 & 2601 \\
9 & 35 & 43 & 1505 & 1225 & 1849 \\
10 & 41 & 55 & 2255 & 1681 & 3025 \\
11 & 34 & 42 & 1428 & 1156 & 1764 \\
12 & 41 & 55 & 2255 & 1681 & 3025 \\
13 & 36 & 45 & 1620 & 1296 & 2025 \\
14 & 43 & 56 & 2408 & 1849 & 3136 \\
15 & 33 & 41 & 1353 & 1089 & 1681 \\
16 & 40 & 53 & 2120 & 1600 & 2809 \\
17 & 34 & 43 & 1462 & 1156 & 1849 \\
18 & 39 & 54 & 2106 & 1521 & 2916 \\
19 & 35 & 44 & 1540 & 1225 & 1936 \\
\hline
\end{tabular}

${ }^{21}$ Ibid., hlm.223

${ }^{23}$ Ibid., hlm.101

${ }^{24}$ Ibid., hlm.102

${ }^{22}$ Ibid., hlm. 101 


\begin{tabular}{|c|c|c|c|c|c|}
\hline 20 & 42 & 54 & 2268 & 1764 & 2916 \\
21 & 35 & 45 & 1575 & 1225 & 2025 \\
22 & 41 & 54 & 2214 & 1681 & 2916 \\
23 & 36 & 42 & 1512 & 1296 & 1764 \\
24 & 41 & 53 & 2173 & 1681 & 2809 \\
25 & 34 & 40 & 1360 & 1156 & 1600 \\
26 & 40 & 52 & 2080 & 1600 & 2704 \\
27 & 31 & 39 & 1209 & 961 & 1521 \\
28 & 38 & 49 & 1862 & 1444 & 2401 \\
29 & 33 & 39 & 1287 & 1089 & 1521 \\
30 & 39 & 49 & 1911 & 1521 & 2401 \\
31 & 34 & 42 & 1428 & 1156 & 1764 \\
32 & 40 & 53 & 2120 & 1600 & 2809 \\
33 & 33 & 40 & 1320 & 1089 & 1600 \\
34 & 41 & 53 & 2173 & 1681 & 2809 \\
35 & 35 & 46 & 1610 & 1225 & 2116 \\
36 & 40 & 54 & 2160 & 1600 & 2916 \\
\hline & $\sum \mathrm{X}$ & $\sum \mathrm{Y}$ & $\sum$ & $\sum \mathrm{X}^{2}$ & $\sum \mathrm{Y}^{2}$ \\
& & & $\mathrm{X} . \mathrm{Y}$ & & \\
\hline & 134 & 1704 & 6419 & 50434 & 8188 \\
& 2 & & 7 & & 8 \\
\hline
\end{tabular}

Selanjutnya mencari $r_{\text {hitung }}$ dengan langkah sebagai berikut:

$$
\begin{aligned}
& r x y=\frac{N\left(\sum X \cdot y\right)-\left(\sum x\right) \cdot\left(\sum y\right)}{\left.\sqrt{\left[N \cdot \sum X^{2}-(\Sigma X)^{2}\right]-\left[N \cdot \sum Y^{2}\right.}-\left(\sum y\right)^{2}\right]} \\
& \mathrm{rxy}= \\
& \frac{36(64197)-(1342) \cdot(1704)}{\sqrt{\left[36(50434)^{2}-(1342)^{2}\right] \cdot\left[36(81888)^{2}-(1704)^{2}\right]}} \\
& \text { rxy } \\
& =\frac{2311092-2286768}{\sqrt{[1815624-1800964]} \cdot[2947968-2903616]} \\
& \mathrm{rxy}=\frac{24324}{\sqrt{14660.44352}} \\
& r x y=\frac{24324}{\sqrt{650200320}} \\
& \mathrm{rxy}=\frac{24324}{25499,0258} \\
& r x y=0,95
\end{aligned}
$$

Berarti besarnya Pengaruh Sertifikasi Terhadap Kedisiplinan Mengajar Guru di Sekolah Dasar Negeri 008 Tembilahan Hulu adalah 0,95.
Untuk mengetahui interprestasi Pengaruh antara Sertifikasi Terhadap Kedisiplinan Mengajar Guru di Sekolah Dasar Negeri 008 Tembilahan Hulu dapat diinterprestasikan sebagai berikut:

\section{Tabel Interprestasi}

\begin{tabular}{|c|c|}
\hline $\mathbf{R}$ & Interprestasi \\
\hline $0,80<\mathrm{r} \leq 1,00$ & Sangat Tinggi \\
$0,60<\mathrm{r} \leq 0,80$ & Tinggi \\
$0,40<\mathrm{r} \leq 0,60$ & Cukup \\
$0,20<\mathrm{r} \leq 0,40$ & Rendah \\
$\mathrm{r} \leq 0,20$ & Sangat Rendah \\
\hline
\end{tabular}

Berdasarkan tabel di atas nilai $\mathrm{r} \mathrm{x} \mathrm{y}=$ 0,80 berada pada interval $0,80-1,00$. Dengan demikian dapat disimpulkan Pengaruh Sertifikasi Terhadap Kedisiplinan Mengajar Guru di Sekolah Dasar Negeri 008 Tembilahan Hulu yaitu berada dalam kategori "Sangat Tinggi".

Langkah selanjutnya adalah menentukan besarnya sumbangan variabel $\mathrm{X}$ terhadap variabel $\mathrm{Y}$ adalah sebagai berikut:

$$
\begin{aligned}
\mathrm{KP} & =\mathrm{r}^{2} \times 100 \% \\
& =0,95^{2} \times 100 \% \\
& =0,9025 \times 100 \% \\
& =90,29 \%
\end{aligned}
$$

Artinya Pengaruh Sertifikasi Terhadap Kedisiplinan Mengajar Guru di Sekolah Dasar Negeri 008 Tembilahan Hulu adalah 90,29\%.

Selanjutnya untuk mengetahui ada pengaruh yang signifikan antara Sertifikasi Terhadap Kedisiplinan Mengajar Guru, maka dengan menentukan taraf signifikansi dengan melihat $\mathrm{r}_{\text {tabel }}$ dalam $0,5(5 \%)$.

$\mathrm{Df}=\mathrm{N}-\mathrm{nr}=18-2=16$

Dengan memeriksa tabel nilai " $\mathrm{r}$ " Product Moment df sebesar 34 pada taraf signifikansi $5 \%$ diperoleh $\mathrm{r}_{\text {tabel }}=0,413$. Karena r x y $=4>t_{\text {tabel }}=1,691$, maka pada 
taraf 5\% hipotesa nol (Ho) ditolak dan hipotesa (Ha) diterima.

Dengan demikian dapat disimpulkan bahwa terdapat Pengaruh Sertifikasi Terhadap Kedisiplinan Mengajar Guru di Sekolah Dasar Negeri 008 Tembilahan Hulu.

Selanjutnya membanding nilai $t_{\text {hitung dangan }} t_{\text {tabel }}$ sebagai berikut:

$$
\begin{aligned}
& \mathrm{t}_{\text {hitung }}=\frac{\sqrt[\mathrm{r}]{\mathrm{n}-2}}{\sqrt{\mathrm{I}-\mathrm{r}^{2}}} \\
& \mathrm{t}_{\text {hitung }}=\frac{\sqrt[0,95]{36-2}}{\sqrt{\mathrm{I}-0,95^{2}}} \\
& \mathrm{t}_{\text {hitung }}=\frac{0,95 \sqrt{34}}{\sqrt{\mathrm{I}-0,9025^{2}}} \\
& \mathrm{t}_{\text {hitung }}=\frac{\sqrt[0,95]{34}}{\sqrt{0,0975}} \\
& \mathrm{t}_{\text {hitung }}=\frac{0,95.5,83}{0,0975} \\
& \mathrm{t}_{\text {hitung }}=\frac{5,5385}{0,3122} \\
& \mathrm{t}_{\text {hitung }}=17,74 \\
& \text { Jadi, } \mathrm{t}_{\text {hitung }}=17,74
\end{aligned}
$$

Berdasarkan perhitungan di atas dengan $t_{\text {hitung }}$ yaitu 17,74 lebih besar dari $\mathrm{t}_{\text {tabel }}$ yaitu 1,691. Dengan demikian dapat disimpulkan bahwa Sertifikasi ada pengaruh terhadap Kedisiplinan Mengajar Guru di Sekolah Dasar Negeri 008 Tembilahan Hulu.

Dari hasil pengujian didapatkan hasil $t_{\text {hitung: }} 17,74 \geq t_{\text {tabel: }}: 1,691$.

Jika: $t_{\text {hitung }} \geq t_{\text {tabel }}$ di tolak Ho artinya signifikan.

$t_{\text {hitung }} \leq t_{\text {tabel }}$ diterima Ho artinya tidak signifikan.

Karena $t_{\text {hitung }} \geq$ (Lebih besar dari)

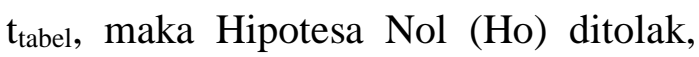
berbunyi "terdapat Pengaruh Sertifikasi Terhadap Kedisiplinan Mengajar Guru di Sekolah Dasar Negeri 008 Tembilahan".

Sebaliknya, jika Hipotesa Alternatif (Ha) diterima, maka berbunyi "Tidak terdapat Pengaruh Sertifikasi Terhadap Kedisiplinan Mengajar Guru di Sekolah Dasar Negeri 008 Tembilahan”.

\section{KESIMPULAN}

Terdapat Pengaruh Sertifikasi Terhadap Kedisiplinan Mengajar Guru di Sekolah Dasar Negeri 008 Tembilahan Hulu dengan hasil thitung adalah 17,74. Sedangkan ttabel adalah 1,691, jadi, t. hitung > t tabel, Maka Ho di tolak Ha diterima berarti terdapat terdapat Pengaruh Sertifikasi Terhadap Kedisiplinan Mengajar Guru di Sekolah Dasar Negeri 008 Tembilahan Hulu.

\section{REFERENSI}

Anas Sudijono, 2008, Pengantar Statistik Pendidikan, Jakarta: Raja Grafindo Persada.

Departemen Pendidikan dan Kebudayaan, Kamus Besar Bahasa Indonesia, 1995, Jakarta: Balai Pustaka.

Dimyati, Mudjiono, 2000, Belajar dan Pembelajaran, Jakarta: PT Rineka Cipta.

Dirjen Dikdasmen, 1996, Pengelolaan Sekolah di Sekolah Dasar, Jakarta: Depdikbud.

Emzir, 2010, Metodologi Penelitian Pandidikan Kuantitatif dan Kualitatif, Jakarta: Rajawali Pers.

Hadeli, 2006, Metode Penelitian Kependidikan, Ciputat: Quantum Teaching.

J.B. Situmorang, Winarno, 2008, Pendidikan Profesi dan Sertifikasi Pendidik, Klaten: Saka Mitra Kompetensi.

Joko Subagyo, 2006, Metode Penelitian dalam Teori dan Praktik, Jakarta: Rineka Cipta.

Kusnadi, 2011, Profesi dan Etika Keguruan, Pekan Baru: Yayasan Pustaka Riau. 
Masnur Muslich, 2007, Sertifikasi Guru Menuju Profesionalisme Pendidik, Jakarta: PT Bumi Aksara.

Martinis Yamin, Maisah, 2010, Standarisasi Kinerja Guru, Jakarta: Gaung Persada.

Moh. Uzer Usman, 2004, Menjadi Guru Profesional, Bandung: PT Remaja Rosdakarya.

Mulyasa, E, 2009, Standar kompetensi dan Sertifikasi Guru, Bandung: PT Remaja Rosdakarya.

Nurul Zuriah, 2006, Metodologi Penelitian Sosial dan Pendidikan Teori Aplikasi, Jakarta: Bumi Aksara.

Oemar Hamalik, 2001, Proses Belajar Mengajar, Jakarta: PT Bumi Aksara.

Oemar Hamalik, 2004, Pendidikan Guru Berdasarkan Pendekatan Kompetensi, Jakarta: PT Bumi Aksara.

Pusat Bahasa Departemen Pendidikan Nasional Edisi ketiga, Kamus Besar Indonesia, 2002, Jakarta: Balai Pustaka,

Riduan, 2005, Belajar Mudah Penelitian, Bandung: Alfabeta.

SardimanAm, 2001, Interaksi dan Motivasi Belajar Mengajar, Jakarta: PT Raja Grafindo Persada.

Subana, Moersetyo Rahardi, Sudrajat, 2000, Statistik Pendidikan, Bandung: Pustaka Setia.

Suharsimi Arikunto, 2002, Prosedur Penelitian Suatu Pendekatan Praktek, Jakarta: Rineka Cipta.

S. Margono, 2003, Metodologi Penelitian Pendidikan, Jakarta: Rineka Cipta.

Sukardi, 2003, Metodologi Penelitian Kompetensi dan Praktiknya, Jakarta: PT Bumi Aksara.

Tim Penyusun Kamus Pusat Pembina dan Pengembangan Bahasa, Kamus Umum Bahasa Indonesia, 1995, Jakarta: PT Balai Pustaka. 